\title{
BLE PIGMENTS IN THE STOOLS OF INFANTS
}

\author{
BY \\ S. D. V. WELLER \\ From The Hospital for Sick Children, Great Ormond Street, London
}

(Received for Publication March 8, 1950)

In the normal person bilirubin is converted in the gut into stercobilin. However, unaltered bile pigment occurs in meconium and in the stool of any individual with much intestinal hurry, and has also been shown to be passed at times by some older infants, though this fact does not seem to be widely known. The absence of stercobilin from the stool is usually taken as evidence for total biliary obstruction, and infants with unduly prolonged neonatal jaundice may thus be suspected of having atresia of the bile ducts. Such children have been transferred to this hospital where the absence of stercobilin has been confirmed, but abundant bilirubin has been found in the stools. These children have made a spontaneous recovery.

\section{The Present Investigation}

It was decided to take a random sample of infants under 4 months of age who were not suspected of having obstructive jaundice and to test their stools for bilirubin and stercobilin.

The methods used were the qualitative ones described by Harrison (1947). Fouchet's reagent was used to detect bilirubin, and a spectroscopic examination was made for stercobilin. These tests are quick and simple to perform and are probably the ones most used in England at the present time. They are not very delicate, but it was felt that this was an advantage, since we wished to discover whether a normal infant could ever produce a stool containing so little pigment that it could not be qualitatively detected by these usual tests. Ladd (1935) pointed out that babies with total biliary atresia may pass a small amount of pigment, which presumably reaches the interior of the gut either in bile-stained digestive secretions or by desquamation of jaundiced epithelial cells. In our experience of these cases the qualitative tests used in this investigation have always given either a totally negative result or indicated only a very faint trace of pigment.

One hundred and two infants admitted to the hospital were tested, some on several occasions, and where stercobilin was absent at the first test, further specimens were examined at intervals until the pigment appeared, or until the baby died or was discharged.

\section{Results}

Stercobilin was not detected in the stools of 23 children. Of these, 21 gave a negative reaction at the first test, and two gave a similar reaction when the pigment had previously been present. Neither of these two children had diarrhoea or jaundice at the time. Another child gave negative tests up to the 161 st day of life, a positive being recorded on the 167th day.

Fourteen of these 23 children were observed to develop a positive test for stercobilin. Coincidentally the bilirubin reaction became weaker or negative.

No stool (in over 160 tests) was devoid of both pigments.

Of the 102 children, 21 were totally breast-fed up to the time of the test, and all gave a positive Fouchet test in their stools. The stercobilin results are shown according to age distribution in Table 1.

TABLE 1

Analysis of Stercobitin Results

\begin{tabular}{|c|c|c|c|c|c|c|c|}
\hline Age (weeks) & $0-4$ & $5-8$ & $9-12$ & $13-15$ & $16-20$ & $20-$ & Totals \\
\hline Stercobilin $\div$ & 1 & 9 & 1 & 1 & & & 12 \\
\hline Stercobilin - & 3 & 3 & 1 & & 1 & 1 & 9 \\
\hline
\end{tabular}

It will be readily seen that a negative stercobilin test was common in the first weeks; in fact, of the six youngest children in the series, only one (aged 4 days) showed a spectroscopic band of stercobilin. It was absent in $43 \%$ of all the breast-fed cases.

There were 81 children who had been bottle-fed to some extent before the test. Many had been partially or totally on the breast at an earlier period. Bilirubin was found in the stools of about half (40 cases). Where it was present in small quantity, stercobilin was always found, but where there was a large amount of bilirubin, stercobilin was usually 
absent. Table 2 shows the stercobilin results in age groups.

TABLE 2

Stercobiun Results According to Age Groups

\begin{tabular}{l|c|c|c|c|c|c}
\hline Age (weeks) & $0-4$ & $5-8$ & $9-12$ & $13-16$ & $17-20$ & Totak \\
\hline Steroobilin + & 15 & 20 & 22 & 7 & 5 & 69 \\
\hline Steroobilin - & 4 & 3 & 3 & 2 & & 12 \\
\hline
\end{tabular}

Stercobilin was therefore absent from less than $15 \%$ of the stools of bottle-fed babies at the first test. This finding was unusual even in the first month of life, but did occur in normal children up to at least 16 weeks of age.

Combining the two tables, the total figures reached are those of Table 3.

TABLE 3

Combined Stercobiun Results

\begin{tabular}{l|c|c|c|ccc|c|c}
\hline Age (weeks) & $0-4$ & $5-8$ & $9-12$ & $13-16$ & $17-20$ & $20+$ & Totals \\
\hline Stercobilin + & 16 & 29 & 23 & 8 & 5 & & 81 \\
\hline Stercobilin - & 7 & 6 & 4 & 2 & 1 & 1 & 21 \\
\hline
\end{tabular}

The colour of the stools was not a reliable index of the pigment content. Several pale green stools gave a negative Fouchet's test, and three whitish specimens contained stercobilin. The stercobilinnegative and bilirubin-negative stools showed the same wide range of colours.

No significant correlation was found between stool pigment and any particular condition for which admission to hospital had been advised.

\section{Discussion}

It is obvious that testing for stercobilin alone cannot prove jaundice to be obstructive in an infant. Our results indicate that either bilirubin or stercobilin is always present in the stool of a normal child, and that tests for both pigments must be used. The absence of both is strong evidence for total biliary obstruction. Further, it is possible in normal infants for stercobilin to disappear temporarily. The two babies in whom this occurred were bottlefed at the time, and stercobilin remained absent for two and three weeks repectively,

The unreliability of the stercobilin test is greater in the first two months of life, and greater in breastfed than bottle-fed babies.

Comparison of Tables 1 and 2 suggests (though the figures are not large enough to do more) that bilirubin normally persists for some time in the stools of breast-fed babies; that stercobilin is absent at least as often as it is present in breast-fed infants under one month old; and that stercobilin tends to appear carlier in bottle-fed babies.

It has been known at least since 1840 that unchanged bile pigments may predominate in the stools of newborn infants (Simon). Since that time the pigment excretion in the faeces has been studied by various workers, and Schorlemmer (1900) pointed out that stercobilin appeared later in the stools of breast-fed than artificially fed babies. Isolated observations have been made of bilirubin being present for long periods - up to 14 months (Giaume and Lanza, 1929) - but it usually disappears earlier than this. Certainly the age by which bilirubin disappears from the stool is variable and may depend on the bacterial population of the gut, and this in turn may be affected by the diet and manner of feeding.

A number of quantitative studies of faecal pigment excretion have been made since Ylppö (1913) estimated the bilirubin output in the first 14 days of life. Snelling (1933) studied the urobilinogen (stercobilin) excretion. Ross, Waugh, and Malloy (1937), in an investigation of icterus neonatorum, made quantitative estimations of the pigments in the stools and urine of normal babies in the first week of life. All 35 babies investigated showed measurable quantities of both urobilin and bilirubin throughout the first week. In fact, their figures were startingly higher than those of earlier workers, ranging from 11.5 to $57.5 \mathrm{mg}$. of bilirubin per day, and from 33.5 to $69.3 \mathrm{mg}$. of urobilin per day. Tat, Greenwalt, and Dameshek (1943) in a similar investigation found far smaller amounts, their figures for the first five days being from 1 to $23 \mathrm{mg}$. (average $8.6 \mathrm{mg}$.) per day of bilirubin, and from a trace to $0.7 \mathrm{mg}$. of urobilin per day. Thus they found about a quarter as much bilirubin and a fiftieth as much urobilin. These discrepancies are remarkable. It is perhaps significant that there are so many different methods for the estimation of these pigments, and this may reflect their unreliability. At any rate, no group of workers in this field has used methods identical with those employed by others. It would seem that the problem of the quantitative excretion of bile pigments needs more exhaustive investigation.

Behrendt (1949) in his work on diagnostic tests for infants and children states that in the differential diagnosis of jaundice 'in over half of the cases, the diagnosis of obstructive jaundice can be made by analysing the urine for bilirubin and urobilinogen.' He neither discusses the value of tests on the stools nor describes any method for detection of stool pigments, nor does he describe how the diagnosis of obstructive jaundice is reached in the cases where urinary analysis is inconclusive. 
The tests employed in this investigation are easy to perform, quick and widely used in this country, and the results show that so long as both tests are employed it is improbable that a case of neonatal jaundice will be falsely labelled obstructive.

\section{Summary}

Over 160 stools were tested from 102 infants under 4 months of age without obstructive jaundice. In $20 \%$ of babies stercobilin was not detected. It is therefore necessary to test for both bilirubin and stercobilin to prove biliary obstruction in children of this age group.

I should like to express my deep indebtedness to Dr. W. W. Payne for his help and advice in this work, and to his technical staff for their unfailing cooperation.

Behrendt, H. (1949). 'Diagnostic Tests for Infants and Children,' p. 27. New York.

Giaume, C., and Lanza, P. (1929). Pediatria, 37, 519.

Harrison, G. A. (1947). 'Chemical Methods in Clinical Medicine,' 3rd ed., pp. 485, 505. London.

Ladd, W. E. (1935). Ann. Surg., 102, 742.

Ross, S. G., Waugh, T. R., and Malloy, H. T. (1937). J. Pediat., 11, 397.

Schorlemmer, R. (1900). Arch. Verdaukr., 6, 263.

Simon, J. F. (1840). Arch. Pharm., Berl., 22, 35.

Snelling, C. E. (1933). J. Pediat., 2, 399.

Tat, R. J., Greenwalt, T. J., and Dameshek, W. (1943). Amer. J. Dis. Child., 65, 558.

Ylppö, A. (1913). Z. Kinderheilk., 9, 208. 